Proceedings of the 10th International Ruminant Reproduction Symposium (IRRS 2018); Foz do Iguaçu, PR, Brazil, September 16th to 20th, 2018.

\title{
Influences of nutrition and metabolism on reproduction of the female ruminant
}

\author{
Ana Meikle ${ }^{1, *}$, Victoria de Brun ${ }^{1}$, Mariana Carriquiry ${ }^{2}$, Pablo Soca ${ }^{2}$, Cecilia Sosa ${ }^{3}$, \\ María de Lourdes Adrien ${ }^{1}$, Pablo Chilibroste ${ }^{2}$, José Alfonso Abecia ${ }^{3}$ \\ ${ }^{1}$ Facultad de Veterinaria, Udelar, Montevideo, Uruguay. \\ ${ }^{2}$ Facultad de Agronomía, Udelar, Montevideo, Uruguay. \\ ${ }^{3}$ Facultad de Veterinaria, Universidad de Zaragoza, Zaragoza, Spain.
}

\begin{abstract}
Beef cows and ewes grazing native pastures are exposed to cycles of undernutrition that reflect the seasonal variations of biomass production. In grazing dairy cows, the physiological undernutrition during early lactation due to increased demands for lactation and low dry matter intake is exacerbated by the need to get sufficient intake from pasture and the extra grazing energy costs. Undernutrition has profound impacts on reproduction by affecting multiple reproductive processes at different levels of the reproductive axis. The objective of this paper is to review the influence of undernutrition on reproductive events of the adult female ruminant, with emphasis on both grassland and mixed rain-fed grazing farming systems. The comparative endocrinology and reproductive biology among ewes, beef and dairy cows may provide a comprehensive knowledge of the metabolic and reproductive adaptation to feed restriction. Understanding the critical underlying physiological mechanisms by which nutrition affects reproduction is the base of focus feeding strategy to improve the reproductive performance of the female ruminant.
\end{abstract}

Keywords: metabolism, reproduction, ruminant.

\section{Introduction}

The world's population numbered nearly 7.6 billion in 2017, a large proportion of its increase has been in developing countries where livestock production is a major factor of agriculture growth (Food and Agriculture Organization - FAOSTATS, 2017). Despite the ability of herbivores to convert human-inedible fibrous biomass into human-edible food, the sustainability of this food production is under discussion (Gill et al., 2010). The innovations in livestock practices in the last decades resulted in increased animal production. However, the increase in the concentration of greenhouse gases and of minerals in surface and ground water in high-density livestock operations, illustrates that current livestock practices do not meet the definitions of environmental sustainability (Van Vuuren and Chilibroste, 2013). In this scenario, grasslands and mixed rain-fed systems (i.e., farming practices that rely on rainfall for water availability) constitute an alternative for sustainable livestock production. Moreover, maximizing the proportion of pastures in the diet is a pivotal factor for minimising production costs.

Grasslands $(25 \%$ earth surface; FAOSTATS, 2017) are found primarily in marginal areas unfit for cropping. Native pastures are exposed to high variability in biomass production throughout the year due to normal seasonal variation and increasingly abnormal, extreme climate events. These seasonal variations, also influenced by the stocking rate, are normally absorbed by body weight loss during the winter or dry periods, and gain during the summer or rainy periods. Thus, cows and ewes managed under extensive grassland systems are exposed to a structural underfeeding system (i.e. annual periods of feed restriction due to low herbage mass production by native pastures). Reproductive function is aligned closely with food supply, which is easily exemplified by the seasonality of sheep to ensure birth during seasons that are favourable for lamb survival. While the initial events of the reproductive process (ovulation/fertilization/early gestation) do not demand relevant amounts of energy, the requirements during late gestation and lactation are considerable, and disruptive events may be lifethreatening to the mother and the offspring. However, since the initial reproductive events are sensitive to fluctuations of nutrient availability, the efficient use of energy of the adult female in the reproductive cycle is maximized. Although meat production has increased during the last decades (FAOSTATS, 2017), reproductive efficiency remains low, with calving rates around 60 to $65 \%$ (Pallarés et al., 2005). In beef cows, poor nutritional status (reflected in low body condition scores, BCS) together with calf presence/suckling, determines long postpartum anestrus, early embryonic death, reduced pregnancy and weaning rates (Stagg et al., 1998; Hess et al., 2005; Diskin and Morris, 2008)

In mixed rain-fed dairy systems in which herbage is the primary diet component, in contrast with indoor systems (total mixed ration, TMR), prediction of nutrient availability is complex since it includes uncertainties associated with grazing. Moreover, grazing dairy cows do not take in sufficient dry matter intake (DMI) to sustain the high milk production that could be achieved with their actual genetic potential (Kolver and Muller, 1998). Maximizing DMI is crucial to achieve the desired milk production as well as to minimize the magnitude and duration of the negative energy balance (NEB). The NEB is known to decouple energy requirements of lactation and nutrient supply that takes place during the transition period (Drackley, 1999). The biological processes affected after decades 
of selection for milk production resulted in physiological undernutrition during early lactation (Chilliard, 1999). Although several reports have showed the abrupt decline in fertility in dairy cows worldwide (Butler, 2000; Lucy, 2001), the improved management in nutrition, health and reproduction, and the genetic selection for health and fertility traits, have changed this trend in the last years in some countries (Berry et al., 2014; Thatcher, 2017).

The present review will focus on the effects of NEB on reproductive performance of adult female ruminants, with emphasis on both grassland and mixed rain-fed grazing farming systems. Whilst early investigations focused on the effects of nutrition on the hypothalamic-pituitary axis, studies of the last decade have tested the hypothesis that nutritional signals (metabolic hormones) also exert direct effects at peripheral levels. The potential causes of reproductive failure include impaired folliculogenesis, abnormalities of the ovum/embryo, luteal inadequacy and/or failure of the supply of progesterone to the uterus, abnormal functionality of the reproductive tract and disruption of maternal recognition of pregnancy.

\section{Ruminant metabolic adaptation to undernutrition: endocrine signals}

The metabolic adaptation to undernutrition implies adjustments in nutrient partitioning that are regulated by complex signalling pathways among organs and tissues, and depends on multiple intrinsic and extrinsic factors (see Fig. 1). Faced with nutritional deficiency, and depending on its severity, the natural physiological response is to renounce reproduction. As an immediate response in the adult female, cyclicity would be compromised; if this limitation is overcome, the next challenge is pregnancy success and/or the number of offspring (Scaramuzzi et al., 2006). Even among sequential reproductive events, undernutrition influences may tip the balance towards success or failure in certain steps of the reproductive cycle. Although biological processes are similar among sheep and cows, ruminant females may show different adaptive mechanisms depending on the species and their environments. For instance, the reproductive responses of the adult female to NEB include the increase in the duration of seasonal anestrus (ewes), postpartum anestrus (cows), decreased fertilization rate and/or increased embryo mortality (Butler, 2000; Hess et al., 2005; Forcada and Abecia, 2006; Diskin and Morris, 2008; see Fig. 2). The outcome will vary depending on the energy status and the presence of the offspring (Short et al., 1990; Stagg et al., 1998). Moreover, the metabolic and reproductive responses to undernutrition depend on recent (feeding level) or more longer term metabolic history (reflected in the body reserves, Chilliard et al., 2005). Thus, to understand the influences of undernutrition and metabolism on female reproduction, these aspects have to be considered, as changes in nutrient flux will affect reproductive processes.
Undernutrition and/or NEB in the female ruminant is characterized by decreased blood glucose, insulin and insulin-like growth factor-I (IGF-I), and increased concentrations of non-esterified fatty acids (NEFA; Ciccioli et al., 2003; Meikle et al., 2004a; Lake et al., 2006; Sosa et al., 2006a). These metabolic adaptations are coordinated not only by changes in the plasma concentration of key hormones, but by tissuespecific variations in hormonal sensitivity and responsiveness (Bauman, 2000; see Fig. 1). During NEB, the growth hormone (GH)-IGF axis is uncoupled in the liver, resulting in a reduction of circulating IGF-I, despite high $\mathrm{GH}$ concentrations (Kobayashi et al., 1999). This uncoupling may be the result of a state of hepatic resistance to $\mathrm{GH}$ due to decreased mRNA expression of the $\mathrm{GH}$ receptor (GHR), especially its isoform $1 \mathrm{~A}$, which occurs during NEB in dairy cows (Kobayashi et al., 1999). The increased GH concentration in early lactation promotes mobilization of NEFA from adipose tissue and their oxidative use by the rest of the body (Bauman, 2000; Block et al., 2001). Thus, anabolism is inhibited directly by the decrease in insulin concentrations and increased insulin resistance of tissues, and indirectly by the lack of insulin stimulation of GHR that limits hepatic synthesis of IGFI (Butler et al., 2003; Rhoads et al., 2004; Fig. 1). Information about the effect of undernutrition/NEB on the hepatic molecular mechanism that explains the uncoupling of GH-IGF axis may differ according to species and/or management. Indeed, although blood IGF-I concentrations were decreased during NEB, no reduction in hepatic $G H R-1 A$ and $I G F-I$ mRNA were observed in beef cattle and sheep (Jiang et al., 2005; Sosa et al., 2006a; Astessiano et al., 2014; Laporta et al., 2014). In addition, the activity of IGF-I is modulated by complex interactions with specific binding proteins (IGFBPs) that alter the availability of the active growth factor and its cellular receptors (Jones and Clemmons, 1995). Most IGF-I is bound to IGFBP3 and the acid-labile subunit in a ternary complex. The NEB is associated with decreased IGFBP3 and increased IGFBP2 shifting this binding to IGFI/IGFBP2 complex and reducing the half-life of IGF-I (Jones and Clemmons, 1995; Laporta et al., 2014). In our experiments, plasma IGF-I turned out to be the best marker integrating the static (body reserves) and acute effects of nutrition in sheep (Fernández-Foren et al., 2011), dairy (Meikle et al., 2004a; Adrien et al., 2012) and beef cows (Soca et al., 2013a; Laporta et al., 2014). Indeed, Adrien et al. (2012) suggested that insulin profiles were associated more to day-to-day nutritional inputs, while IGF-I profiles more likely reflected the changes in energy balance. Both, insulin and IGF-I, affect the reproductive axis at central (hypothalamuspituitary gland) and peripheral (gonads, reproductive tract and embryo) levels (Fig. 1).

The adipose tissue plays a role not only in energy storage, but is also an active endocrine tissue sensing metabolic status. Leptin and adiponectin concentrations have been proposed as indexes of metabolic status, as well as metabolic signals to the reproductive system (Blache et al., 2000; Kim et al., 2011). Plasma concentrations of leptin decrease with undernutrition in sheep and cows (Delavaud et al., 
2000; Ciccioli et al., 2003; Meikle et al., 2004a; Sosa et al., 2006a; Fig. 1), which facilitates a decrease in metabolic rate and enhances voluntary feed intake (Ingvartsen and Boisclair, 2001). As leptin is mainly synthetized by adipocytes, the decrease in leptin concentrations after restriction in dairy and beef cows and ewes is greater in females with more adipose tissue that also have higher initial concentrations of leptin (Meikle et al., 2004a; Fernández-Foren et al., 2011; Astessiano et al., 2014). Data on adiponectin in undernourished female ruminants are limited. A negative association between adiponectin concentrations and BCS is reported in dairy cows during the dry period (De Koster et al., 2017) and during the postpartum period in beef cows (Astessiano et al., 2014). Interestingly, in dairy cows, both leptin and adiponectin concentrations decrease around calving, and increase thereafter (Giesy et al., 2012; Singh et al., 2014; Astessiano et al., 2015). Since adiponectin suppresses gluconeogenesis (Zhou et al., 2005), its reduction may imply a physiological mechanism to increase glucose supply to the mammary gland for milk production (Saremi et al., 2014).

The regulation of these hormones is interdependent (e.g., each hormone affects the synthesis/secretion of the other) to facilitate crosstalk among tissues regulating metabolism (liver, pancreas, adipose tissue, Fig. 1), as reported for these species and rodents (Wabitsch et al., 1996; Rhoads et al., 2004; Yoshida et al., 2007). Thus, the different metabolic responses to undernutrition found among studies can be attributed, among other factors, to differences in body reserves. Indeed, differential BCS responses induced experimentally in sheep (Fernández-Foren et al., 2011), beef (Ciccioli et al., 2003) and dairy cows (Chagas et al., 2006; Adrien et al., 2012) were associated with different metabolic responses. Even if underfed ewes had decreased glucose concentrations, insulin concentrations decreased abruptly immediately after undernutrition in lean $\operatorname{BCS}(<2.25$, scale $0-5)$ ewes, while in moderate BCS $(>2.75)$ ewes the decrease in insulin concentrations was observed two weeks after the start of the treatments (Fernández-Foren et al., 2011). Thus, metabolic adaptation to feed restriction depends on body reserves: females with very low energy stores respond rapidly (in terms of metabolites/hormones) to DMI, while the response of animals with greater energy stores seems to be somewhat delayed.

In grazing dairy cows, pre-partum IGF-I and/or leptin concentrations were associated with the level of body reserves in both naturally occurring or induced BCS (Meikle et al., 2004a; Chagas et al., 2006; Adrien et al., 2012). In contrast, subtle or no associations were detected between pre-partum BCS and leptin/IGF-I concentrations after calving in the latter studies. Increased leptin and IGF-I concentrations after calving were reported in response to greater concentrate intake (Reist et al., 2003). Indeed, greater plasma insulin and IGF-I concentrations were found in dairy cows fed a TMR compared to grazing dairy cows, even if offered more than $35 \mathrm{~kg} \mathrm{DM} /$ cow/day of herbage and also supplemented to cover maintenance energy requirements plus 10 liters of milk (Meikle et al., 2013). This was consistent with the higher nutrient density of
TMR diets and no extra requirements to cover grazing activities or walking. When beef cows were classified according to their BCS at calving ( $<3.5 \geq$, scale 1-8), IGF-I concentrations during prepartum were greater in moderate than low-BCS cows, with no differences during the postpartum (Astessiano et al., 2014). In addition, beef cows grazing high herbage allowance of native pastures during the annual gestation-lactation cycle presented greater BCS and higher IGF-I concentrations than cows grazing low herbage allowance, but also serum IGF-I increased in early spring in response to pasture availability and energy balance only in the high allowance group (Laporta et al., 2014). Similarly, when temporary suckling restriction was applied to primiparous beef cows two months after calving, the increase in IGF-I concentrations was greater in cows with moderate $(\geq 4$, scale $1-8)$ vs. low $(\leq 3.5) \mathrm{BCS}$ at calving (Soca et al., 2013a). Moreover, the endocrine response of these cows to flushing (supplementation for 22 days immediately after suckling restriction) was dependent on BCS at calving, as IGF-I and insulin concentrations increased in moderate BCS cows but did not change in low BCS cows. Overall, the endocrine response to nutritional management depends, at least partially, on body reserves.

In addition, metabolic adaptation to lactation is affected by age (parity): primiparous cows, which have not reached their adult body size and continue growing during pregnancy and lactation, present metabolic differences respect to older cows (Wathes et al., 2007). The competing demands of the mammary gland are superimposed on the requirements for growth, and both insulin and IGF-I stimulate growth. The profiles of these hormones and metabolites, such as NEFA, during the transition period according to parity have been inconsistent (Vandehaar et al., 1999; Meikle et al. 2004a). Wathes et al. (2007) modelled metabolic traits, milk yield and BCS, and reported greater IGF-I concentrations in primiparous cows, which may limit nutrient partitioning into milk. In contrast to multiparous cows, there was no relationship between insulin concentration and milk production in primiparous cows. The authors suggested that insulin is less important in controlling the relative partitioning of nutrients between body tissue and milk synthesis, possibly due to the prevailing higher IGF-I concentration in primiparous cows still growing. Moreover, body reserves are usually related to parity, as primiparous dairy and beef cows under pasture-based systems present better BCS than multiparous cows probably for not having the energy demands of a previous lactation. Thus, prepartum leptin concentrations are generally higher in primiparous cows (Meikle et al., 2004a; Wathes et al., 2007). On the other hand, a steeper decrease in body reserves and leptin concentrations was observed during early lactation in primiparous cows when compared to multiparous cows (Meikle et al., 2004a). As both categories are usually managed together under grazing conditions, this may be also explained by a dominance effect for food availability (Grant and Albright, 2001). These confounding factors should be considered since they are at the basis of the poor reproductive performance. 


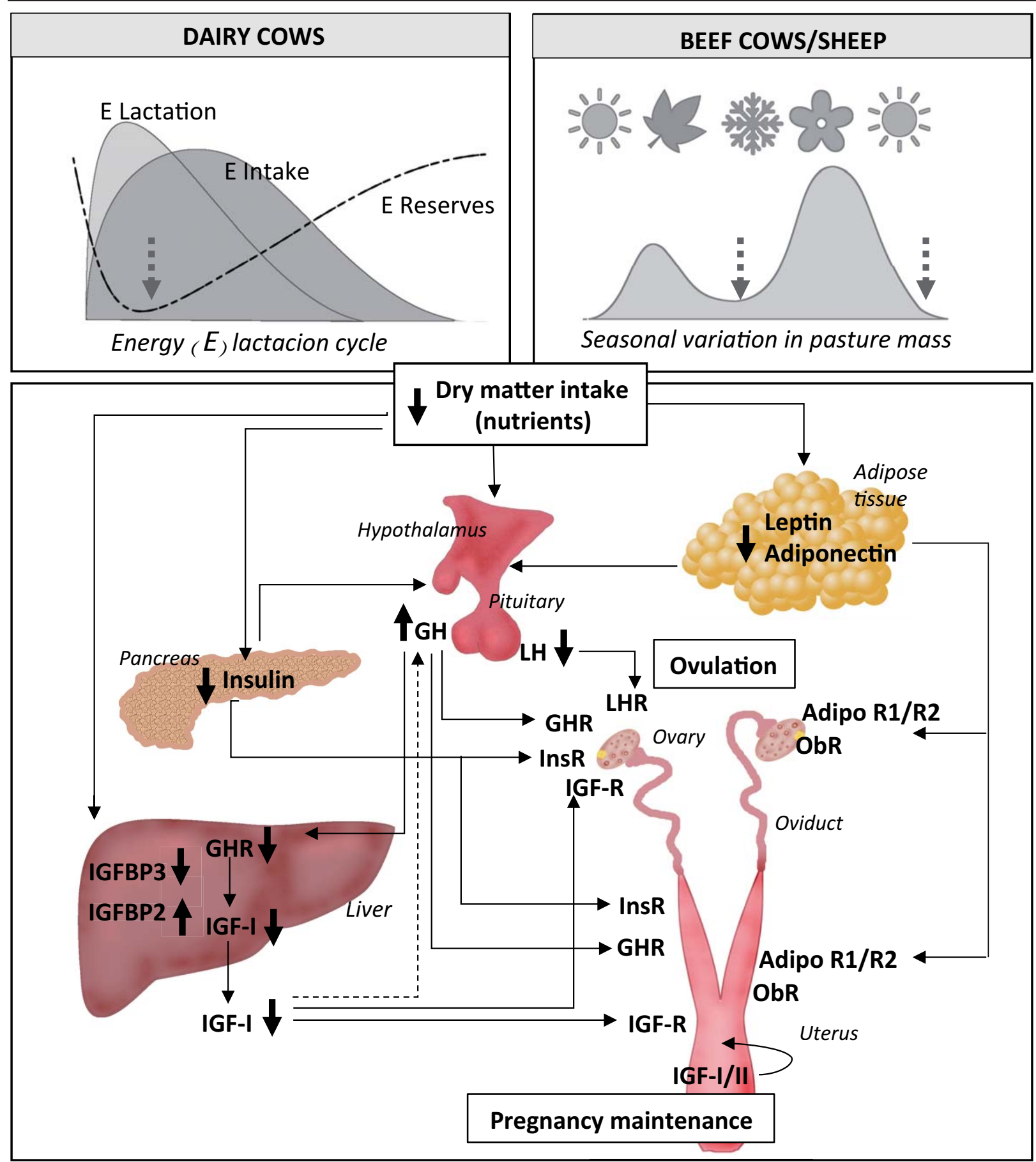

Figure 1. Simplified model of metabolic influences on reproduction of the female adult ruminant. While undernutrition in grazing beef cows and ewes is the result of energy intake below their requirements associated with the seasonal variation in pasture mass, in grazing dairy cows the negative energy balance (NEB) is the consequence of the increased demands for lactation and the low dry matter intake exacerbated by the need to get sufficient intake from pasture and the extra grazing energy costs. Grazing management interacts with parity in the metabolic adaptation to restricted dry matter intake or NEB that also depends on body reserves (metabolic memory). Reproductive events are affected by how and when this adaptation takes place. The nutrient flux affects all tissues and nutrient partitioning is modulated by the endocrine signals. Peripheral tissues (liver, adipose tissue, pancreas and others) secrete signals that not only regulate metabolic pathways, but also inform of the energy status. Hormones interact with each other by regulating their synthesis/secretion to ensure a coordinated regulation of energy partitioning. A complex system in the hypothalamus senses nutrient restriction and regulates voluntary feed intake, nutrient partitioning and reproductive function accordingly. The reproductive axis will respond both hierarchically by regulation of hypothalamus-pituitary gland and at follicular level (i.e., hormone receptors of the metabolic hormones) sensing the metabolic status to overcome the first reproductive limitation in the adult female, which is the pospartum/seasonal anestrus. The endocrine signals have also direct effects on the reproductive tract where they may tip the balance towards pregnancy success or failure. Broken lines: decrease, i.e., negative feedback IGF-I/GH, which is diminished and contributes to higher GH concentrations. Solid lines: increase (positive effect). 


\section{Follicular and luteal function and physiology of the reproductive tract}

Follicular diameter has been associated positively with acquisition of oocyte competence (Arlotto et al., 1996) and with enhanced embryo growth and development since the corpus luteum (CL) originated from these follicles secretes more progesterone (P4) concentrations to improve maintenance of pregnancy (Vasconcelos et al., 2001; Perry et al., 2007). Reduced feed intake has been associated with decreased follicle size in cows (Burns et al., 1997). Undernourished ewes presented a reduced number of large follicles compared to control ewes (McNeilly et al., 1987). Moreover, undernourished ewes presented larger follicles in the static phase that were functionally altered because there was no inhibition in development of subordinate follicles (Sosa et al., 2010).

The ability of the dominant follicle to grow and ovulate depends on LH pulsatility as well as concentration of many growth factors (e.g, IGF family) and nutrients (Fortune et al., 2004; Fig. 2). The changes that take place in the dominant follicle (e.g, LH sensitivity and content of steroidogenic enzymes) allow $17-\beta$ estradiol (E2) secretion and subsequent ovulation (Crowe et al., 2014). Thus, undernutrition and/or NEB delays ovulation by inhibition of LH frequency and diminished concentrations of IGF-I/insulin and other nutrients, which reduce E2 production by the dominant follicles (Butler, 2000; Fig. 2). Follicular fluid plays a critical role whereby the microenvironment impacts on oocyte development and future embryo quality (Fortune et al., 2004; Revelli et al., 2009). Increased concentrations of E2 and E2/P4 ratio in follicular fluid have been associated with improved follicular growth and follicle dominance, oocyte quality and pregnancy outcome (Revelli et al., 2009). Differences in metabolomic profiles of follicular fluid in cows with different energy balances have been reported (Forde et al., 2015) and some components have been associated (positively: alanine and linolenic acid; negatively: total fatty acids and urea) with oocyte competence (Matoba et al., 2014).

Beef cows with moderate $\mathrm{BCS}$ at calving or grazing high herbage allowance had greater maximum diameter of dominant follicles during the postpartum when compared with low BCS cows or low herbage allowance, respectively (Quintans et al., 2010; Carriquiry et al., 2011). The E2/P4 ratio did not differ in the preovulatory follicle of beef cows grazing high vs. low herbage allowance. However, intrafollicular IGF-I concentrations were greater in cows grazing high herbage allowance of native pastures consistent with an earlier postpartum ovulation in these cows (Carriquiry et al., 2011). Likewise, there is an inverse relationship between plasma IGF-I/insulin and duration of postpartum anestrus in beef and dairy cows (Lucy, 2001; Meikle et al., 2004; Quintans et al., 2010; Soca et al., 2013a; Laporta et al., 2014).

The magnitude of NEB and its association with the different types of anestrus have been reviewed before (Peter et al., 2009). The first postpartum follicular wave takes place within 10-14 days after calving and the fate of the dominant follicle will depend on LH pulsatilty and the availability of many growth factors within the follicle. Thus, the first pospartum ovulation in well-managed dairy cows will take place within the first month after calving (Crowe et al., 2014; Fig. 2). In grazing dairy cows $(n=824$ in 7 commercial herds) with none, one or two previous calvings, milk P4 was determined twice weekly for 90 days after calving to monitor luteal activity: $53 \%$ of the cows ovulated within 30 days after calving, 14\% from 30 to 40 days, and lower percentages were found until 90 days after calving, while $13 \%$ of the cows did not ovulate during this period (Meikle, 2018; Facultad de Veterinaria, Udelar, Montevideo, Uruguay; unpublished data). Although dairy cattle usually present a more profound NEB due to lactation than beef cattle grazing pastures, the latter suffer a prolonged restricted nutrient availability in addition to suckling (Fig. 2). The major physiological difference between dairy and beef cows during early postpartum is the lower frequency of LH pulses in beef cows due to suckling inhibition and presence of calf (see Fig. 2). While dairy cows may ovulate in the first follicular wave, in beef cows if nutrition is adequate, the first postpartum ovulation takes place on the third follicular wave ( $\sim 30$ days), but if beef cows present poor body condition, ovulation is delayed ( $\sim 70-100$ days, reviewed by Crowe et al., 2014).

The resumption of ovarian cyclicity after calving associated with body reserves is well documented. Indeed, in grazing production systems dairy and beef cows with better BCS during the pre and postpartum periods, or with better BCS at calving, had an earlier first postpartum ovulation (Meikle et al., 2004a; Quintans et al., 2010; Soca et al., 2013b). Soca et al. (2013b) determined that the length from calving to first ovulation in beef cows decreased by 49 days for each incremental unit of improvement of BCS at calving (scale 1 to 8). Stagg et al. (1995) reported a prolonged period of anestrus in cows with poor body condition. Likewise, increased BCS advanced first ovulation by 59 days in high vs. low herbage allowance cows (Laporta et al., 2014). Although less data on postpartum resumption of ovarian cyclicity is available in sheep, it was shown that the first postpartum ovulation in the breeding season was delayed in undernourished ewes with low BCS $(<2.75$, scale 0 to 5) at lambing in comparison to undernourished ewes with moderate BCS $(>2.75)$ or control ewes (Sosa et al., 2006b). The relevance of BCS also was documented in its effect on the length of seasonal anestrus and ovulation rate, as ewes with a moderate BCS $(>2.75)$ had a shorter seasonal anestrus (64 days) than ewes with a low $\mathrm{BCS}(<2.75 ; 113$ days) and a higher rate of double ovulation as observed by the greater mean number of CLs (1.67 vs. $1.08 \mathrm{CL}$, respectively), especially in the transition between seasonal anestrus and the breeding season (Forcada and Abecia, 2006). These data show that the resumption of postpartum/seasonal ovarian cyclicity depends on female body reserves. 


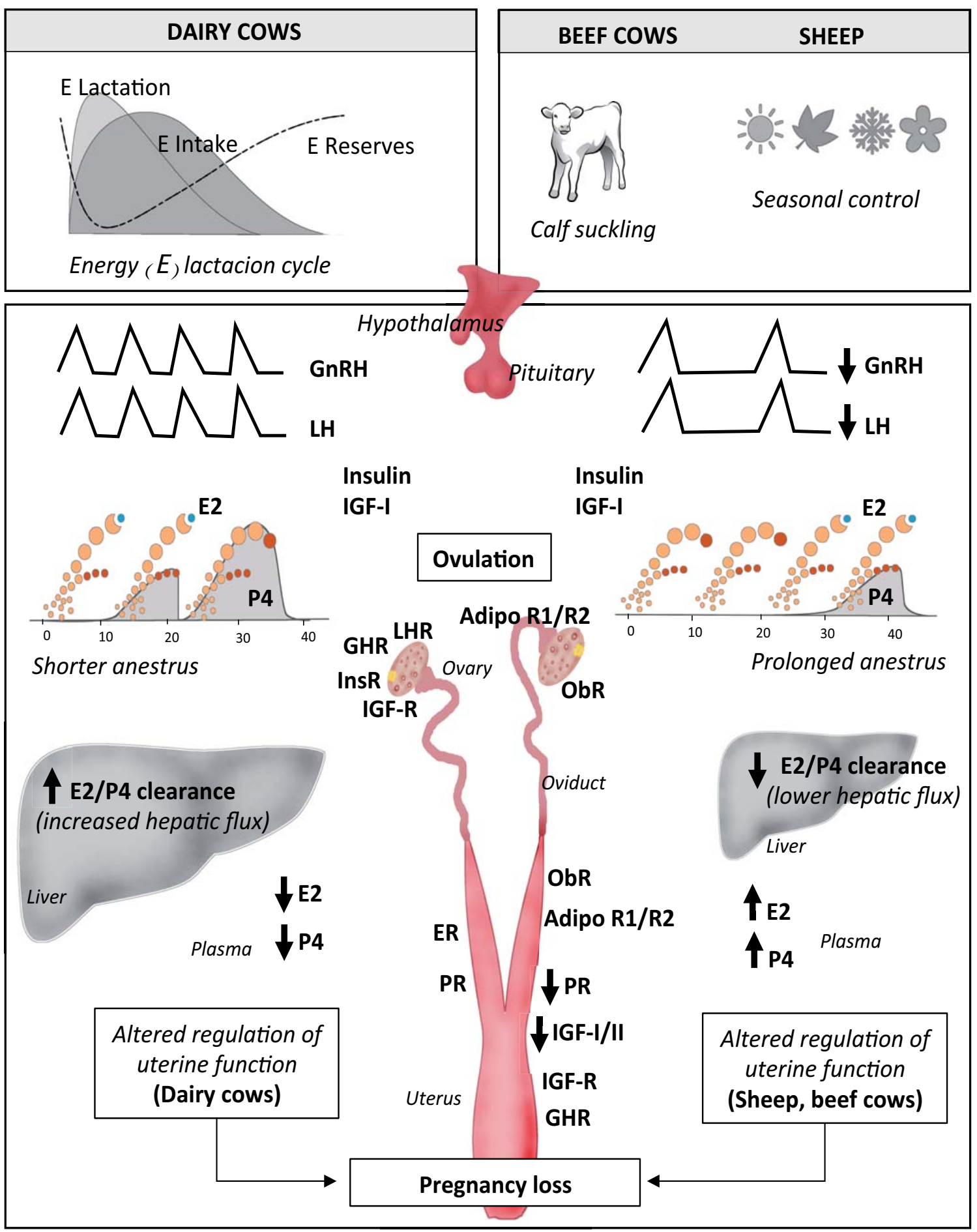

Figure 2. Proposed model of reproductive responses to negative energy balance (NEB) and environment in dairy and beef cows and ewes. Although dairy cows usually present a more profound NEB due to lactation requirements than beef cows and ewes grazing pastures, the later may suffer a more prolonged restricted nutrient availability. Beef cows and ewes present low frequency of LH pulses (suckling or seasonal inhibition, respectively) and undernutrition prolongs pospartum or seasonal anestrus, respectively. Although severe NEB also prolongs pospartum anestrus in dairy cows, is comparatively shorter. Body reserves affect the length of pospartum (dairy and beef cows) and seasonal anestrus (ewes). Once ovulation has occurred, the sequential preparation of the oviducts and uterus by E2 and P4 sustains embryo growth. Clearance of E2 and P4 is affected by liver metabolic flux: in dairy cows the high hepatic flux (intake-lactation) is related to low steroid plasmatic concentrations, whereas in ewes undernutrition is associated with high steroid circulating concentrations (no data as such was found in beef cows). In both dairy cows and sheep, data indicate that uterine sensitivity to P4 (PR) is diminished in NEB, as well as uterine sensitivity to other metabolic hormones. These findings may explain the embryo losses. Embryo mortality seems to be more important in the high producing dairy cow than in beef cows and ewes. The schematic representation of follicular waves in dairy and beef cows has been taken from Crowe et al. (2014). 
Parity is a relevant factor when considering postpartum resumption of ovarian cyclicity, which occurred 16-23 days later in primiparous than multiparous grazing dairy cows (Meikle et al., 2004a; Adrien et al., 2012). This is consistent with the lower percentage of inseminated primiparous cows in the first 80 days after calving compared to multiparous cows (39.8 vs. 50.4\%, 3772 dairy cows from 12 commercial farms; Cruz, 2018; Facultad de Veterinaria, Udelar, Montevideo, Uruguay; unpublished data). On the other hand, conception rate at first service in the later study was higher in primiparous cows (49.4 vs. 38.1\%). Similar data was reported in pasture-based dairy systems (for reviews, see Rhodes et al., 2003 and Roche et al., 2011). In high-producing confined dairy herds, Santos et al. (2009) reported that multiparous cows were more likely to start ovarian cyclicity earlier than primiparous cows, but conception rate on day 30 after AI ( $\sim 100$ days after calving) was higher in primiparous cows (41.1 vs. 36.1\%). Thus, although NEB heavily influences postpartum resumption of ovarian cyclicity, it only explains partially the decreased reproductive efficiency due to nutrition.

Once ovulation and fertilization has occurred, an adequate functionality of the oviduct and uterine horn is essential for the maintenance of pregnancy. The morphological, histological and biochemical changes of the reproductive tract are modulated by the fluctuating concentrations of E2 and P4 acting through their specific receptors in the target tissues, which also vary during the estrous cycle and early pregnancy (Meikle et al. 2001, 2004b; Robinson et al. 2001; Binelli et al., 2018). Thus, their function can be modified by manipulating the growth of the preovulatory follicle and its associated E2 secretion, as well as the consequent CL formation and associated P4 production (Mesquita et al., 2015; Ramos et al., 2015). Indeed, a positive association between preovulatory concentrations of E2 and the duration of proestrus regarding the uterine environment and fertility was found (Bridges et al., 2010, 2012). Pugliese et al. (2016) showed that the diameter of the preovulatory follicle and its blood flow and size, vascularization of CL and pregnancy rates were greater in beef cows ovulating large follicles. Moreover, Ramos et al. (2015) reported decreased uterine redox capacity in cows that ovulated a smaller follicle during early diestrus, and the authors suggested that it might be one of the causes of the reduced fertility found in these animals. Recently, de la Mata et al. (2018) demonstrated that extending the proestrus interval increased the rate of the dominant follicle growth from the time of P4 device removal to ovulation, the luteal area and serum $\mathrm{P} 4$ concentrations, which were associated with endometrial differences in PR immunostaining, $P R$ and $I G F-I$ mRNA expression, and pregnancy rates.

Progesterone supports the secretory function of the endometrium that sustains conceptus elongation and further implantation (for a review see Spencer et al., 2007). Moreover, there is a positive relationship between P4 concentrations during the early luteal phase and the synthesis of the embryo signal, interferon tau $(\mathrm{IFN}-\tau)$. The IFN- $\tau$, by altering uterine gene expression, modifies the episodic $\mathrm{PGF}_{2 \alpha}$ release that is responsible for the luteal regression (Mann and Lamming, 2001). Different authors have managed to modify endometrial function and improve embryo growth by injecting P4 during the early luteal phase in the female ruminant (Robinson et al., 1989; Forde et al., 2009). However, results are not consistent as effects depend on many factors, e.g., the timing of start and the duration of P4 supplementation affect CL and embryo development in beef heifers (Parr et al., 2017). Moreover, Bisinotto et al. (2015) reported that P4 supplementation during timed AI programs in cows without a CL at the start of the treatment improved pregnancy per timed AI, but P4 supplementation had no positive effect in cows that had a CL at time of supplementation.

In sheep, P4 concentrations are 800-fold higher in the ovarian than in the jugular vein, but did not differ between high and low feeding levels (reviewed by Abecia et al., 2006). On the other hand, plasma P4 concentrations were negatively associated with the level of feed intake, with higher P4 concentrations in underfed ewes likely due to lower liver steroid metabolism, thus a lower clearance rate (Rhind et al., 1989b; Lozano et al., 1998; see Fig. 2). In dairy cows, increased feed intake has been associated with the increase of E2 and P4 clearance (Sangsritavong et al., 2002), which can contribute to inadequate endometrial functionality. On the other hand, plasma P4 circulating concentrations may not reflect actual P4 concentrations in the reproductive tract. Indeed, in the ruminant, P4 is transferred locally from the ovarian/oviductal veins to the uterine arterial segments adjacent to the ovary (Weems et al., 1989). Although receptors specifically bind hormones with high specificity, few studies have analysed $\mathrm{P} 4$ and its receptor (PR) concentrations where transfer systems are in place in the fed restricted female ruminant. The region and side of the uterus affect transcript abundance in bovine endometrium (Sponchiado et al., 2017). Also, a differential oviductal gene expression associated with CL location was reported (de Brun et al., 2013) in agreement with greater $\mathrm{P} 4$ concentrations in the ipsilateral oviduct of recipient ewes (Graña et al., 2018; Facultad de Veterinaria, Udelar, Montevideo, Uruguay; unpublished data). These specific molecular differences according to location are of functional importance: when sheep IVF zygotes were transferred to oviducts ipsilateral and contralateral to the $\mathrm{CL}$ on day 1 , a greater recovery rate and a lower proportion of degenerated embryos were found in the ipsilateral uterine horn on day 6 (de Brun et al., 2016a).

In cyclic undernourished ewes, higher plasma but lower endometrial P4 concentrations were found on day 5 (Lozano et al., 1998). This was later explained by the lower expression of $P R$ mRNA, and lower PR protein abundance and binding capacity in uterus/oviduct of undernourished ewes (Sosa et al., 2006a; Fig. 2). As P4 regulates endometrial gene expression, differences in uterine P4 sensitivity (PR) were associated with different functionality and early embryo growth, as reported for different sheep breeds (Sequeira et al., 2016). Indeed, undernutrition in sheep 
was also associated with a lower expression of $I G F-I$ mRNA in uterus and $I G F-I I$ mRNA in oviduct at day 5 of pregnancy (de Brun et al., 2013; Fig. 2). Overall, these findings support the concept that local P4 concentrations (i.e. oviducts and uterine horns), and the consequent differential regulation of the reproductive tract physiology, may explain the higher embryo losses found in undernourished ewes (Rhind et al., 1989a, b).

The effect of underfeeding and/or NEB on gene expression in the reproductive tract of cyclic and/or postpartum cows has also been investigated. Endometrial and oviductal gene expression of IGF signaling pathways and several metalloproteinases were altered in dairy cows in severe NEB two weeks after calving (Wathes et al., 2011). It was suggested that altered postpartum functionality of the tract might affect tissue repair with consequent lower fertility. Less data are available regarding NEB on uterine gene expression in lactating cows at breeding time. Rhoads et al. (2008) reported no changes in mRNA endometrial expression of $G H R$ and $I G F B P 2$ in lactating cows on 40,80, 120 and 160 days after calving, although higher IGF-I mRNA levels were found on day 160; it was suggested that days in milk had a small effect on uterine gene expression. In a recent study in lactating dairy cows, Astessiano et al. (2017) reported greater intercaruncular endometrial mRNA expression of $I G F-I, I G F B P 3, P R$ and adiponectin receptors on day 7 of the estrous cycle at the end of the voluntary waiting period when cows fed a TMR and high herbage allowance were compared to medium and/or low herbage allowance cows (Fig. 2). Thus, the ruminant endometrium seems to be able to sense the metabolic status and to adapt its physiology accordingly, thereby determining possible success or failure of pregnancy.

\section{Uterine functionality during early pregnancy}

Although the preimplantation embryo is to a certain extent metabolically autonomous, the fate of the embryo is affected by the nutritional status of the maternal unit. Maternal undernutrition in sheep results in retarded embryonic development at 8 to 11 days after mating and reduced pregnancy rates after 2 weeks of pregnancy (Rhind et al., 1989a; Abecia et al., 2006). Although relatively high fertilization rates are found in dairy cows, conception rates are low (Lucy, 2001; Diskin and Morris, 2008). The proportion of embryos recovered from lactating cows was lower than from dry cows, consistent with the lower embryo quality reported for high-producing dairy cows (Sartori et al., 2010). Data suggest an effect of the energy balance on the functionality of the reproductive tract as reviewed previously (Sartori et al., 2010; Lonergan et al., 2016).

Much focus has been put on the effects of NEB around the moment of maternal recognition of pregnancy (i.e., day 14 in sheep, and day 17 in cows). In dairy cows, at day 17-intercaruncular endometrium, genes were differentially expressed according to pregnancy and lactation (Cerri et al., 2012; Thompson et al., 2012). Lactation altered the metabolic status (lower glucose and IGF-I plasma concentrations) and decreased P4 plasma concentrations (Thompson et al., 2012). The presence of the embryo had profound effects on endometrial expression of genes involved in immune pathways, but lactation also upregulated genes related to immunoglobulins, so that it was suggested that lactation could cause an immune imbalance with potential negative effects on conceptus survival (Cerri et al., 2012). Moreover, lactation affected the expression of genes involved in glucose homeostasis suggesting that it could be deleterious for the embryo. Lesage-Padilla et al. (2017) demonstrated that day 19-intercaruncular endometrium of pregnant lactating cows presented greater mRNA expression of oxidative stress-related genes when compared to pregnant dry cows, suggesting that lactation is associated with an increase in reactive oxygen species in the endometrium. As endometrial expression of conceptus-regulated genes was not affected by the metabolic status, it was suggested that the endometrial ability to respond to embryonic signals when implantation occurs seems not to be affected by maternal metabolism (Lesage-Padilla et al., 2017). No reports on the effect of NEB on local P4 endometrial concentrations and its association with uterine gene expression in pregnant or cyclic dairy cows have been found.

Lower fertilization (27\%) and transferability $(30 \%)$ rates were observed in undernourished superovulated donor ewes when compared to well-fed ewes (Abecia et al., 2015). When only good quality embryos $(n=2)$ from undernourished and control superovulated donor ewes were transferred to undernourished and control recipient ewes, no differences in pregnancy rates were found at day 18 , but recipient undernourished ewes had a higher occurrence of late embryonic mortality (from days 18-40; de Brun et al., 2016b). These ewes had lower plasma insulin and P4 concentrations during the early luteal phase, which may have affected conceptus development leading to pregnancy loss after day 18. Overall, data suggest that when morphologically good quality embryos are transferred, maintenance of pregnancy relies on the nutrition of the mother regardless of embryo origin.

Embryos collected on day 15 of pregnancy from underfed ewes ( 0.5 maintenance requirements) secreted lower amounts of IFN $\tau$ in vitro, and the endometrial tissue collected from those ewes secreted higher amounts of PGF $2 \alpha$ than control ewes (Abecia et al., 2006). Since this was accompanied by a reduction in embryo survival, it was suggested that the lower fertility observed in underfed ewes could be mediated through altered signals of maternal recognition of pregnancy. Further studies showed no effects of undernutrition on the intercaruncular endometrial expression of candidate genes involved in mechanisms of maternal recognition of pregnancy in pregnant ewes (such as PR, estrogen and oxytocin receptors, cyclooxygenase 2 and members of the IGF family) on day 14 (Sosa et al., 2009). It was suggested that conceptuses present in the uterus of undernourished mothers managed to elicit effects similar to those in well-fed pregnant ewes. In order to gain in-depth knowledge of the underlying mechanisms, we have studied the uterine transcriptome of the same 
ewes (de Brun et al., 2016c). Interestingly, pregnancy in control ewes upregulated the gene expression of the citrate cycle and oxidative phosphorylation pathways, suggesting increased energy use by the endometrium to maintain pregnancy, as was previously reported in pregnant dairy cows (Cerri et al., 2012). In contrast, pregnancy in undernourished ewes did not affect these pathways, but upregulation of catabolic pathways for fatty acids and amino acids was observed (de Brun et $a l ., 2016 \mathrm{c}$ ). Moreover, undernutrition in pregnant ewes induced a 9-fold change in acyl-CoA synthetase shortchain family member 2 (an enzyme that converts acetate to acetyl-CoA) mRNA expression compared to control pregnant ewes. This differential response is indicative that endometrial cells utilize energy from these pathways, probably sparing glucose for utilization by the embryo. The immune system is also critical for proper embryo development and is activated in pregnant animals from both nutritional groups. Intercaruncular endometrium from pregnant ewes had a 3.4-fold or 2.0fold greater expression of interferon-induced helicase $\mathrm{C}$ domain1 (IFIH1) than cyclic ewes in control or undernourished ewes respectively (de Brun, 2018; Facultad de Veterinaria, Udelar, Montevideo, Uruguay; unpublished data). The IFIH1 gene modulates local immune cells in the endometrium during pregnancy (Song et al., 2007). In the same study, the chemokine CXCL10, a promoter of trophoblast growth migration and adhesion (Nagaoka et al., 2003) was upregulated more than 6 and 3 -fold in pregnant vs. cyclic control and undernourished ewes respectively (de Brun, 2018; Facultad de Veterinaria, Udelar, Montevideo, Uruguay; unpublished data), which could be associated with less efficient growth or adhesion of the embryo in undernourished ewes. Genes participating in the biosynthesis of unsaturated fatty acids were highly downregulated in undernourished pregnant compared with control pregnant ewes, which could be consistent with an energy-sparing mechanism. On the other hand, as unsaturated fatty acids are precursors for various eicosanoids and prostaglandins involved in the adhesion of the ovine trophoblast to the endometrium and in vascular permeability (Salleh, 2014), the downregulation observed in pregnant underfed ewes may be related with the greater late embryo mortality detected in undernourished animals (de Brun et al., 2016b). Overall, the endometrial machinery appears to have an adaptive ability to respond to adverse changes in metabolic status due to feed restriction that is dependent on presence of the embryo.

\section{Concluding remarks}

The ruminant adult female reproductive physiology is highly influenced by the environment and energy intake is a pivotal factor. Depending on the degree of energy deficit, the reproductive adaptation to metabolic distress may range from an increased duration of postpartum or seasonal anestrus to impairment of pregnancy establishment. The metabolic adaptation to NEB depends on body reserves that also modulate reproductive responses. The challenge to improve sustainable livestock production resides in maintaining reproductive efficiency of the female ruminant while facing periods of undernutrition, both in grassland (beef and sheep) or mixed rain-fed farming systems (dairy cows). The goals are to identify the biological reproductive processes that are most affected by NEB, and to determine when and how they can be improved by management complementary to cultural, economic and environmental sustainable systems.

\section{Acknowledgments}

The authors are very grateful to Professors William W. Thatcher and Mats Forsberg for their critical correction of the manuscript and invaluable contributions.

\section{References}

Abecia JA, Sosa C, Forcada F, Meikle A. 2006. The effect of undernutrition on the establishment of pregnancy in the ewe. Reprod Nutr Dev, 46:367-378.

Abecia JA, Forcada F, Palacín I, Sánchez-Prieto L, Sosa C, Fernández-Foren A, Meikle A. 2015. Undernutrition affects embryo quality of superovulated ewes. Zygote, 23:116-124

Adrien ML, Mattiauda D, Artegoitia V, Carriquiry M, Motta G, Bentancur O, Meikle A. 2012. Nutritional regulation of body condition score at the initiation of the transition period in primiparous and multiparous dairy cows under grazing conditions: milk production, resumption of postpartum ovarian cyclicity and metabolic parameters. Animal, 6:292-299.

Arlotto T, Schwartz JL, First NL, LeibfriedRutledge ML. 1996. Aspects of follicle and oocyte stage that affect in vitro maturation and development of bovine oocytes. Theriogenology, 45:943-956.

Astessiano AL, Pérez-Clariget R, Quintans G, Soca P, Meikle A, Crooker BA, Carriquiry M. 2014. Metabolic and endocrine profiles and hepatic gene expression in periparturient, grazing primiparous beef cows with different body reserves. Livest Sci, 170:6371.

Astessiano AL, Meikle A, Fajardo M, Gil J, Mattiauda DA, Chilibroste P, Carriquiry M. 2015. Metabolic and endocrine profiles and hepatic gene expression of Holstein cows fed total mixed ration or pasture with different grazing strategies during early lactation. Acta Vet Scand, 16:57-70.

Astessiano AL, Carriquiry M, Mattiauda DA, Adrien ML, Chilibroste P, Meikle A. 2017. Endometrial gene expression in primiparous dairy cows at the end of the voluntary waiting period is affected by nutrition: total mixed ration vs increasing levels of herbage allowance. Reprod Domest Anim, 52:798-805.

Bauman DE. 2000. Regulation of nutrient partitioning during lactation: homeostasis and homeorhesis revisited. In: Cronjé PB (Ed.) Ruminant Physiology: digestion, metabolism, growth and reproduction. Oxon: CABI Publishing. pp. 331-327.

Berry DP, Wall E, Pryce JE. 2014. Genetics and genomics of reproductive performance in dairy and beef 
cattle. Animal, 8(suppl. 1):105-121.

Binelli M, Gonella-Diaza AM, Mesquita FS, Membrive CMB. 2018. Sex steroid-mediated control of oviductal function in cattle. Biology (Basel), 7:pii:E15. doi:10.3390/biology7010015.

Bisinotto RS, Lean IJ, Thatcher WW, Santos JE. 2015. Meta-analysis of progesterone supplementation during timed artificial insemination programs in dairy cows. J Dairy Sci, 98:2472-2487.

Blache D, Tellam RL, Chagas LM, Blackberry MA, Vercoe PE, Martin G. 2000. Level of nutrition affects leptin concentrations in plasma and cerebrospinal fluid in sheep. J Endocrinol, 165:625-637.

Block SS, Butler WR, Ehrhardt RA, Bell AW, Van Amburgh ME, Boisclair YR. 2001. Decreased concentration of plasma leptin in peripar- turient dairy cows is caused by negative energy balance. $J$ Endocrinol, 171:339-348.

Bridges GA, Mussard ML, Burke CR, Day ML. 2010. Influence of the length of proestrus on fertility and endocrine function in female cattle. Anim Reprod Sci, 117:208-215.

Bridges GA, Mussard ML, Pate JL, Ott TL, Hansen TR, Day ML. 2012. Impact of preovulatory estradiol concentrations on conceptus development and uterine gene expression. Anim Reprod Sci, 133:16-26.

Burns PD, Spitzer JC, Henricks DM. 1997. Effect of dietary energy restriction on follicular development and luteal function in nonlactating beef cows. J Anim Sci, 75:1078-1086.

Butler WR. 2000. Nutritional interactions with reproductive performance in dairy cattle. Anim Reprod Sci, 60/61:449-457.

Butler ST, Marr AL, Pelton SH, Radcliff RP, Lucy MC, Butler WR. 2003. Insulin restores GH responsiveness during lactation-induced negative energy balance in dairy cattle: effects on expression of IGF-I and GH receptor 1A. J Endocrinol, 176:205-217.

Carriquiry M, Soca P, Espasandin AC, Meikle A, Viñoles C. 2011. Follicular fluid composition of the preovulatory follicle in beef cows grazing different forage allowances of native pastures. J Anim Sci, 89(Esuppl. 1):93. (Abstract).

Cerri RL, Thompson IM, Kim IH, Ealy AD, Hansen PJ, Staples CR, Li JL, Santos JE, Thatcher WW. 2012. Effects of lactation and pregnancy on gene expression of endometrium of Holstein cows at day 17 of the estrous cycle or pregnancy. J Dairy Sci, 95:56575675

Chagas LM, Rhodes FM, Blache D, Gore PJ, Macdonald KA, Verkerk GA. 2006. Precalving effects on metabolic responses and postpartum anestrus in grazing primiparous dairy cows. J Dairy Sci, 89:19811989.

Chilliard Y. 1999. Metabolic adaptations and nutrient partitioning in the lactating animal. In: Martinet J, Houdebine LM, Head HH (Ed.).Biology of Lactation. Paris: INRA Ed. pp. 503-552.

Chilliard Y, Delavaud C, Bonnet M. 2005. Leptin expression in ruminants: nutritional and physiological regulations in relation with energy metabolism. Domest Anim Endocrinol, 29:3-22.
Ciccioli NH, Wettemann RP, Spicer LJ, Lents CA, White FJ, Keisler DH. 2003 Influence of body condition at calving and postpartum nutrition on endocrine function and reproductive performance of primiparous beef cows. J Anim Sci, 81:3107-3120.

Crowe MA, Diskin MG, Williams EJ. 2014. Parturition to resumption of ovarian cyclicity: comparative aspects of beef and dairy cows. Animal, 8:40-53.

de Brun V, Abecia JA, Fernandez-Foren A, Carriquiry M, Forcada F, Vazquez MI, Meikle A, Sosa C. 2013. Undernutrition and laterality of the corpus luteum affects gene expression in oviduct and uterus of pregnant ewes. Span J Agric Res, 11:989-996.

de Brun V, Meikle A, Cuadro F, Barrera N, dos Santos-Neto PC, Bosolasco D, Crispo M, Menchaca A. 2016a. Embryo development after transfer into the oviduct ipsi or contralateral to corpus luteum in sheep. Anim Reprod, 13:299. (Abstract).

de Brun V, Meikle A, Fernández-Foren A, Forcada F, Palacín I, Menchaca A, Sosa C, Abecia JA. 2016b. Failure to establish and maintain a pregnancy in undernourished recipient ewes is associated with a poor endocrine milieu in the early luteal phase. Anim Reprod Sci, 173:80-86.

de Brun V, Meikle A, Vailati-Riboni M, Bulgari O, Shahzad K, Sosa C, Abecia JA, Loor JJ. 2016c. Effects of undernutrition and the presence of an embryo upon endometrium transcriptome in sheep. In: Abstracts of the 18th International Congress on Animal Reproduction, 2016, Tours, France. Tours: ICAR. pp.19. (Abstract).

De Koster J, Urh C, Hostens M, van den Broeck W, Sauerwein H, Opsomer G. 2017. Relationship between serum adiponectin concentration, body condition score, and peripheral tissue insulin response of dairy cows during the dry period. Domest Anim Endocrinol, 59:100-104.

de la Mata JJ, Núñez-Olivera R, Cuadro F, Bosolasco D, de Brun V, Meikle A, Bó GA, Menchaca A. 2018. Effects of extending the length of pro-oestrus in an oestradiol- and progesterone-based oestrus synchronisation program on ovarian function, uterine environment and pregnancy establishment in beef heifers. Reprod Fertil Dev. doi: 10.1071/RD17473.

Delavaud C, Bocquier F, Chilliard Y, Keisler DH, Gertler A, Kann G. 2000. Plasma leptin determination in ruminants: effect of nutri- tional status and body fatness on plasma leptin concentrations assessed by a specific RIA in sheep. $J$ Endocrinol, 165:519-526.

Diskin MG, Morris DG. 2008. Embryonic and early foetal losses in cattle and other ruminants. Reprod Domest Anim, 43:260-267.

Drackley JK. 1999. Biology of dairy cow during the transition period: the final frontier?. J Dairy Sci, 82:2259-2273

Fernández-Foren A, Abecia JA, Vázquez MI, Forcada F, Sartore I, Carriquiry M, Meikle A, Sosa C. 2011. Restricción alimenticia en ovinos: respuesta endocrino-metabólica dependiente de las reservas corporales. ITEA, 197:1-15.

Food and Agriculture Organization. FAOSTATS. 
2017. Available on: http://www.fao.org/faostat/en/ \#home. Accessed on: October 31, 2017.

Forcada F, Abecia JA. 2006. The effect of nutrition on the seasonality of reproduction in ewes. Reprod Nutr Dev, 46:355-365.

Forde N, Carter F, Fair T, Crowe MA, Evans ACO, Spencer TE, Bazer FW, McBride M, Boland MP, O'Gaora P, Lonergan P, Roche JF. 2009. Progesterone-regulated changes in endometrial gene expression contribute to advanced conceptus development in cattle. Biol Reprod, 81:784-794.

Forde N, O'Gorman A, Whelan H, Duffy P, O'Hara L, Kelly AK, Havlicek V, Besenfelder U, Brennan L, Lonergan P. 2015. Lactation-induced changes in metabolic status and follicular-fluid metabolomic profile in postpartum dairy cows. Reprod Fertil Dev, 28:1882-1892.

Fortune JE, Rivera GM, Yang MY. 2004. Follicular development: the role of the follicular microenvironment in selection of the dominant follicle. Anim Reprod Sci, 82/83:109-126.

Giesy SL, Yoon B, Currie WB, Kim JW, Boisclair YR. 2012. Adiponectin deficit during the precarious glucose economy of early lactation in dairy cows. Endocrinology, 153:5834-5844.

Gill M, Smith P, Wilkinson JM. 2010. Mitigating climate change: the role of domestic livestock. Animal, 4:323-333.

Grant RJ, Albright JL. 2001. Effect of animal grouping on feeding behavior and intake of dairy cattle. Joint ADSA-ASAS Annual Meeting. $J$ Dairy Sci, 84:E156-E163.

Hess BW, Lake SL, Scholljegerdes EJ, Weston TR, Nayigihugu V, Molle JDC, Moss GE. 2005. Nutritional controls of beef cows reproduction. J Anim Sci, 83:90-106.

Ingvartsen KL, Boisclair YR. 2001. Leptin and the regulation of food intake, energy homeostasis and immunity with special focus on periparturient ruminants. Domest Anim Endocrinol, 21:215-250.

Jiang H, Lucy MC, Crooker BA, Beal WE. 2005. Expression of growth hormone receptor 1A mRNA is decreased in dairy cows but not in beef cows at parturition. J Dairy Sci, 88:137-137.

Jones JI, Clemmons DR. 1995. Insulin-like growth factors and their binding proteins: biological actions. Endocr Rev, 16:3-34.

Kim ST, Marquard K, Stephens S, Louden E, Allsworth J, Moley KH. 2011 Adiponectin and adiponectin receptors in the mouse preimplantation embryo and uterus. Hum Reprod, 26:82-95.

Kobayashi Y, Boyd CK, Bracken CJ, Lamberson WR, Keisler DH, Lucy MC. 1999. Reduced growth hormone receptor (GHR) messenger ribonucleic acid in liver of periparturient cattle is caused by a specific down-regulation of GHR 1A that is associated with decreased insulin-like growth factor I. Endocrinology, 140:3947-3954

Kolver ES, Müller LD. 1998. Performance and nutrient intake of high producing Holstein cows consuming pasture or a total mixed ration. J Dairy $S c i, 81: 1403$ 1411.
Lake SL, Scholljegerdes EJ, Nayigihugu V, Murrieta CM, Atkinson RL, Rule DC, Robinson TJ, Hess BW. 2006. Effects of body condition score at parturition and postpartum supplemental fat on adipose tissue lipogenic activity of lactating beef cows. J Anim Sci, 84:397-404.

Laporta J, Astessiano AL, López-Mazz C, Soca P, Espasandin AC, Carriquiry M. 2014. Effects of herbage allowance of native grasslands in purebred and crossbred beef cows: metabolic, endocrine and hepatic gene expression profiles through the gestation-lactation cycle. Animal, 8:1119-1129.

Lesage-Padilla A, Forde N, Poirée M, Healey GD, Giraud-Delville C, Reinaud P, Eozenou C, Vitorino Carvalho A, Galio L, Raliou M, Oudin JF, Richard C, Sheldon IM, Charpigny G, Lonergan P, Sandra O. 2017. Maternal metabolism affects endometrial expression of oxidative stress and FOXL2 genes in cattle. PLoS One, 12:e0189942. doi.org/10.1371/journal.pone.0189942.

Lonergan P, Fair T, Forde N, Rizos D. 2016. Embryo development in dairy cattle. Theriogenology, 86:270277

Lozano JM, Abecia JA, Forcada F, Zarazaga L, Alfaro B. 1998. Effect of undernutrition on the distribution of progesterone in the uterus of ewes during the luteal phase of the estrous cycle. Theriogenology, 49:539-546.

Lucy MC. 2001. Reproductive loss in high-producing dairy cattle: where will it end? J Dairy Sci, 84:12771293.

Mann GE, Lamming GE. 2001. Relationship between maternal endocrine environment, early embryo development and inhibition of the luteolytic mechanism in cows. Reproduction, 121:175-180.

Matoba S, Bender K, Fahey AG, Mamo S, Brennan L, Lonergan P, Fair T. 2014. Predictive value of bovine follicular components as markers of oocyte developmental potential. Reprod Fertil Dev, 26:337345.

McNeilly AS, Jonassen JA, Rhind SM. 1987. Reduced ovarian follicular development as a consequence of low body condition in ewes. Acta Endocrinol (Copenh), 115:75-83

Meikle A, Sahlin L, Ferraris A, Masironi B, Blanc JE, Rodríguez-Irazoqui $M$, Rodríguez-Piñón $M$, Kindahl H, Forsberg M. 2001. Endometrial mRNA expression of oestrogen receptor alpha, progesterone receptor and insulin-like growth factor-I (IGF-I) throughout the bovine oestrous cycle. Anim Reprod Sci, 68:45-56

Meikle A, Kulcsar M, Chilliard Y, Febel H, Delavaud C, Cavestany D, Chilibroste P. 2004a. Effects of parity and body condition score at calving on endocrine and reproductive parameters of the dairy cow under grazing conditions. Reproduction, 127:727-737.

Meikle A, Tasende C, Sosa C, Garófalo EG. 2004b. The role of sex steroid receptors in sheep female reproductive physiology. Reprod Fertil Dev, 16:385394.

Meikle A, Adrien ML, Mattiauda D, Chilibroste P. 2013. Effect of sward condition on metabolic endocrinology during the early postpartum period in 
primiparous grazing dairy cows and its association with productive and reproductive performance. Anim Feed Sci Technol, 186:139-147.

Mesquita FS, Ramos RS, Pugliesi G, Andrade SC, Van Hoeck V, Langbeen A, Oliveira ML, GonellaDiaza AM, Gasparin G, Fukumasu H, Pulz LH, Membrive CM, Coutinho LL, Binelli M. 2015. The receptive endometrial transcriptomic signature indicates an earlier shift from proliferation to metabolism at early diestrus in the cow. Biol Reprod, 93:52. doi: 10.1095/biolreprod.115.129031.

Nagaoka K, Nojima H, Watanabe F, Chang KT, Christenson RK, Sakai S, Imakawa K. 2003. Regulation of blastocyst migration, apposition, and initial adhesion by a chemokine, interferon gammainducible protein $10 \mathrm{kDa}$ (IP-10), during early gestation. J Biol Chem, 278:29048-29056.

Parr MH, Scully S, Lonergan P, Evans ACO, Crowe MA, Diskin MG. 2017. Establishment of critical timing of progesterone supplementation on corpus luteum and embryo development in beef heifers. Anim Reprod Sci, 180:1-9. doi: 10.1016/j.anireprosci.2017.02.005.

Perry GA, Smith MF, Roberts AJ, MacNeil MD, Geary TW. 2007. Relationship between size of the ovulatory follicle and pregnancy success in beef heifers. J Anim Sci, 85:684-689.

Peter AT, Vos PL, Ambrose DJ. 2009. Postpartum anestrus in dairy cattle. Theriogenology, 71:1333-1342.

Pugliesi G, Santos FB, Lopes E, Nogueira E, Maio JR, Binelli M. 2016. Improved fertility in suckled beef cows ovulating large follicles or supplemented with long-acting progesterone after timed-AI. Theriogenology, 85:12391248.

Quintans G, Banchero G, Carriquiry M, LópezMazz C, Baldi F. 2010. Effect of body condition and suckling restriction with and without presence of the calf on cow and calf performance. Anim Prod Sci, 50:931-938.

Ramos RS, Oliveira ML, Izaguirry AP, Vargas LM, Soares MB, Mesquita FS, Santos FV, Binelli M. 2015. The periovulatory endocrine milieu affects the uterine redox environment in beef cows. Reprod Biol Endocrinol, 13:39. doi: 10.1186/s12958-015-0036-X.

Reist M, Erdin D, von Euw D, Tschuemperlin K, Leuenberger H, Delavaud C, Chilliard Y, Hammon HM, Kuenzi N, Blum JW. 2003. Concentrate feeding strategy in lactating dairy cows: metabolic and endocrine changes with emphasis on leptin. J Dairy Sci, 86:1690-1706.

Revelli A, Delle Piane L, Casano S, Molinari E, Massobrio M, Rinaudo P. 2009. Follicular fluid content and oocyte quality: from single biochemical markers to metabolomics. Reprod Biol Endocrinol, 7:40. doi: 10.1186/1477-7827-7-40.

Rhind SM, McKelvey WAC, McMillen S, Gunn RG, Eiston DA. 1989a. Effect of restricted food intake, before and/or after mating, on the reproductive performance of Greyface ewes. Anim Prod, 48:149-155. Rhind SM, McMillen S, Wetherill GZ, Mckelvey WAC, Gunn RG. 1989b. Effects of low levels of food intake before and/or after mating on gonadotrophin and progesterone profiles in Greyface ewes. Anim Prod, 49:267-273.
Rhoads ML, Meyer JP, Lamberson WR, Keisler DH, Lucy MC. 2008. Uterine and hepatic gene expression in relation to days postpartum, estrus, and pregnancy in postpartum dairy cows, $J$ Dairy Sci, 91:140-150.

Rhoads RP, Kim JW, Leury BJ, Baumgard LH, Segoale N, Frank SJ, Bauman DE, Boisclair YR. 2004. Insulin increases the abundance of the growth hormone receptor in liver and adipose tissue of periparturient dairy cows. J Nutr, 134:1020-1027.

Rhodes FM, McDougall S, Burke CR, Verkerk GA, Macmillan KL. 2003. Treatment of cows with an extended postpartum anestrous interval. J Dairy Sci, 86:1876-1894.

Robinson NA, Leslie KE, Walton JS. 1989. Effect of treatment with progesterone on pregnancy rate and plasma concentrations in Holstein cows. J Dairy Sci, 72:202-207.

Robinson RS, Mann GE, Lamming GE, Wathes DC. 2001. Expression of oxytocin, oestrogen and progesterone receptors in uterine biopsy samples throughout the oestrous cycle and early pregnancy in cows. Reproduction, 122:965-979.

Roche JR, Burke CR, Meier S, Walker CG. 2011. Nutrition $\mathrm{x}$ reproduction interaction in pasture-based systems: is nutrition a factor in reproductive failure? Anim Prod Sci, 51:1045-1066.

Royo Pallarés O, Berretta EJ, Maraschin GE. 2005. The South American Campos ecosystem. In: Suttie JM, Reynolds SG, Batello C (Ed.). Grassland of the World. Rome: FAO. pp. 171-179.

Salleh N. 2014. Diverse roles of prostaglandins in blastocyst implantation. ISci World J, 2014:968141. doi:10.1155/2014/968141.

Sangsritavong S, Combs DK, Sartori R, Armentano LE, Wiltbank MC. 2002. High feed intake increases liver blood flow and metabolism of progesterone and estradiol-17beta in dairy cattle. $J$ Dairy Sci, 85:28312842.

Santos JE, Rutigliano HM, Sá Filho MF. 2009. Risk factors for resumption of postpartum estrous cycles and embryonic survival in lactating dairy cows. Anim Reprod Sci, 110:207-221.

Saremi B, Winand S, Friedrichs P, Kinoshita A, Rehage J, Dänicke S, Häussler S, Breves G, Mielenz M, Sauerwein H. 2014. Longitudinal profiling of the tissue-specific expression of genes related with insulin sensitivity in dairy cows during lactation focusing on different fat depots. PLoS One, 9:e86211. doi: org/10.1371/journal.pone.0086211.

Sartori R, Bastos MR, Wiltbank MC. 2010. Factors affecting fertilisation and early embryo quality in single- and superovulated dairy cattle. Reprod Fertil Dev, 22:151-158.

Scaramuzzi RJ, Campbell BK, Downing JA, Kendall NR, Khalid M, Muñoz-Gutiérrez M, Somchit A. 2006. A review of the effects of supplementary nutrition in the ewe on the concentrations of reproductive and metabolic hormones and the mechanisms that regulate folliculogenesis and ovulation rate. Reprod Nutr Dev, 46:339-354. 
Sequeira M, Pain SJ, de Brun V, Meikle A, Kenyon PR, Blair HT. 2016. Gestation-related gene expression and protein localization in endometrial tissue of Suffolk and Cheviot ewes at gestation day 19, after transfer of Suffolk or Cheviot embryos. Theriogenology, 86:15571565.

Short RE, Bellows RA, Staigmiller R, Berardinelli JG, Custer EE. 1990. Physiological mechanisms controlling anestrus and infertility in postpartum beef cattle. J Anim Sci, 68:799-816.

Singh SP, Häussler S, Heinz JF, Akter SH, Saremi B, Müller U, Rehage J, Dänicke S, Mielenz M, Sauerwein H. 2014. Lactation driven dynamics of adiponectin supply from different fat depots to circulation in cows. Domest Anim Endocrinol, 47:35-46. Soca P, Carriquiry M, Claramunt M, Ruprechter G, Meikle A. 2013a. Metabolic and endocrine profiles of primiparous beef cows grazing native grassland: b) Effects of body condition score at calving, type of suckling restriction and flushing on plasmatic and productive parameters. Anim Prod Sci, 54:862-868.

Soca P, Carriquiry M, Keisler DH, Claramunt $M$, Docarmo M, Olivera-Muzzante J, Rodriguez $\mathbf{M}$, Meikle A. 2013b. Reproductive and productive response to suckling restriction and dietary flushing in primiparous grazing beef cows. Anim Prod Sci, 53:283-291.

Song G, Bazer FW, Spencer TE. 2007. Pregnancy and interferon tau regulate RSAD2 and IFIH1 expression in the ovine uterus. Reproduction, 133:285-295.

Sosa C, Abecia JA, Forcada F, Viñoles C, Tasende C, Valares JA, Palacin I, Martin GB, Meikle A. 2006a Effect of undernutrition on uterine progesterone and oestrogen receptors and on endocrine profiles during the ovine oestrous cycle. Reprod Fertil Dev, 18:447-458.

Sosa C, Abecia JA, Palacín I, Forcada F, Meikle A. 2006b. El reinicio de la ciclicidad ovárica postparto en ovejas está determinado por la condición corporal al parto. In: XXXI Jornadas Científicas y X Internacionales Sociedad Española de Ovinotecnia y Caprinotecnia, Zamora, España. Zamora: ITACYL. pp. 362-365.

Sosa C, Carriquiry M, Fernandez A, Talmon M, Abecia JA, Meikle A. 2009. Effect of undernutrition on the uterine environment during maternal recognition of pregnancy in sheep. Reprod Fertil Dev, 21:869-881.

Sosa C, Gonzalez-Bulnes A, Abecia JA, Forcada F, Meikle A. 2010. Short-term undernutrition affects final development of ovulatory follicles in sheep synchronized for ovulation. Reprod Domest Anim, 45:1033-1038.

Spencer TE, Johnson GA, Bazer FW, Burghardt RC, Palmarini M. 2007. Pregnancy recognition and conceptus implantation in domestic ruminants: roles of progesterone, interferons and endogenous retroviruses. Reprod Fertil Dev, 19:65-78.

Sponchiado M, Souza Gomes N, Kubo Fontes T, Martins T, Collado M, Assumpção A, Pugliesi G, Gouveia M, Binelli M. 2017. Pre-hatching embryodependent and -independent programming of endometrial function in cattle. PLoS One 12:e0175954. doi: 10.1371/journal.pone.0175954.
Stagg K, Diskin MG, Sreenan JM, Roche JF. 1995. Follicular development in long-term anoestrous suckler beef cows fed two levels of energy postpartum. Anim Reprod Sci, 38:49-61.

Stagg K, Spicer LJ, Sreenan JM, Roche JF, Diskin MG. 1998. Effect of calf isolation on follicular wave dynamics, gonadotrophin, and metabolic hormone changes, and interval to first ovulation in beef cows fed either of two energy levels postpartum. Biol Reprod, 59:777-783.

Thatcher WW. 2017. A 100-Year Review: Historical development of female reproductive physiology in dairy cattle. J Dairy Sci, 100:10272-10291.

Thompson IM, Cerri LA, Kim IH, Ealy AD, Hansen PJ, Staples CR, Thatcher WW. 2012. Effects of lactation and pregnancy on metabolic and hormonal responses and conceptus and endometrial gene expression of Holstein dairy cattle. $J$ Dairy Sci, 95:5645-5656.

Van Vuuren A, Chilibroste P. 2013. Challenges in the nutrition and management of herbivores in the temperate zone. Animal, 7:19-28.

Vandehaar MJ, Yousif G, Sharma BK, Herdt TH, Emery RS, Allen MS, Liesman JS. 1999. Effect of energy and protein density of prepartum diets on fat and protein metabolism of dairy cattle in the periparturient period. J Dairy Sci, 82:1282-1295.

Vasconcelos JL, Sartori R, Oliveira HN, Guenther JE, Wiltbank MC. 2001. Reduction in size of the ovulatory follicle reduces subsequent luteal size and pregnancy rate. Theriogenology, 56:307-314.

Wabitsch M, Jensen PB, Blum WF, Christoffersen CT, Englaro P, Heinze E, Rascher W, Teller W, Tornqvist H, Hauner H. 1996. Insulin and cortisol promote leptin production in cultured human fat cells. Diabetes, 45:1435-1438.

Wathes DC, Cheng Z, Bourne N, Taylor VJ, Coffey MP, Brotherstone S. 2007. Differences between primiparous and multiparous dairy cows in the interrelationships between metabolic traits, milk yield and body condition score in the periparturient period. Domest Anim Endocrinol, 33:203-225.

Wathes DC, Cheng Z, Fenwick MA, Fitzpatrick R, Patton J. 2011. Influence of energy balance on the somatotrophic axis and matrix metalloproteinase expression in the endometrium of the postpartum dairy cow. Reproduction, 141:269-281.

Weems CW, Weems YC, Lee CN, Vicent DL. 1989. Progesterone in uterine and arterial tissue and in jugular and uterine venous plasma of sheep. Biol Reprod, 49:1-6.

Yoshida K, Murao K, Imachi H, Cao WM, Yu X, Li J, Ahmed RAM, Kitanaka N, Wong NCW, Unterman TG, Magnuson MA, Ishida T. 2007. Pancreatic glucokinase is activated by insulin-like growth factor-I. Endocrinology, 148:2904-2913.

Zhou H, Song X, Briggs M, Violand B, Salsgiver W, Gulve EA, Luo Y. 2005. Adiponectin represses gluconeogenesis independent of insulin in hepatocytes. Biochem Biophys Res Commun, 338:793-799. 